\title{
PERANCANGAN SISTEM INFORMASI DOKUMENTASI BORANG AKREDITASI PROGRAM STUDI
}

\author{
Ahmaddul Hadi ${ }^{1}$ \\ Khairi Budayawan ${ }^{2}$ \\ Syukhri ${ }^{3}$
}

\begin{abstract}
One of quality assessment and the feasibility of higher education institutions and courses is accreditation. To achieve the desired accreditation value, universities and study programs must adjust the internal conditions in accordance with the standards given by the National Accreditation Board of Higher Education (BAN$P T)$. In most courses, all the data are scattered on different physical information systems and documents so that it takes more time and effort to integrate it into judgment. So required a system that is able to automatically retrieve and display the evaluation results with more efficient time and effort. One form of visualization that can meet it is by using a dashboard system that can integrate the entire contents of the supporting data so that when the evaluation process will get information about what parts are lacking or that already meet the standards.
\end{abstract}

Keywords: Information System, Accreditation Form

\section{INTISARI}

Salah satu penilaian mutu dan kelayakan institusi perguruan tinggi atau program studi adalah akreditasi. Untuk mencapai nilai akreditasi yang diinginkan maka perguruan tinggi dan program studi harus menyesuaikan kondisi internal sesuai dengan standar yang diberikan oleh Badan Akreditasi Nasional Perguruan Tinggi (BAN-PT). Pada kebanyakan program studi, semua data tersebar pada sistem informasi dan dokumen fisik yang berbeda sehingga membutuhkan waktu dan usaha yang lebih untuk mengintegrasikan hingga menilainya. Sehingga diperlukan sebuah sistem yang mampu mengambil dan menampilkan hasil evaluasi secara visual dan otomatis dengan lebih hemat waktu dan usaha. Salah satunya dengan menggunakan sistem dashboard yang dapat mengintegrasikan keseluruhan data pendukung sehingga saat proses evaluasi akan didapatkan informasi mengenai bagian-bagian yang kurang maupun yang sudah memenuhi standar.

Kata Kunci: Sistem Informasi, Borang Akreditasi,

\footnotetext{
${ }^{1}$ Dosen Jurusan Teknik Elektronika FT - UNP
} 


\section{PENDAHULUAN}

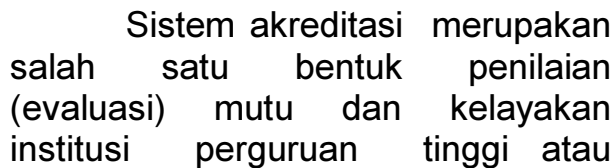
program studi yang dilakukan oleh organisasi atau badan mandiri di luar perguruan tinggi. Penilaian tersebut digunakan sebagai tolak ukur mutu bagi semua program studi dan intitusi pendidikan tinggi baik dari perguruan tinggi negeri maupun swasta yang menyelenggarakan program professional maupun akademik. Semakin baik nilai akreditasi akan berdampak pada pandangan pihak luar mengenai kualitas program studi dan institusi pendidikan tinggi tersebut.

Proses akreditasi dilakukan dalam periode tertentu dan harus diperbarui paling lambat 6 bulan sebelum masa akreditasi berakhir. Instrumen akreditasi program studi terdiri atas: Borang Program Studi atau Borang IIIA, Evaluasi Diri Program Studi, dan Borang yang diisi oleh Fakultas/Sekolah Tinggi. Borang program studi memiliki hasil penilaian $75 \%$ dari skor akhir, sedangkan evaluasi diri program studi memiliki hasil penilaian $10 \%$ dan borang fakultas memiliki $15 \%$ dari skor akhir [1-2]. Elemen-elemen pendukung dalam program studi atau institusi, terutama ketua prodi, dosen, serta tim akreditasi internal perlu melakukan tahap persiapan akreditasi sebelum menggunakan borang yang kemudian dijadikan sebagai dasar dalam penilaian oleh tim BAN- PT.

Permasalahan yang terjadi
adalah mengorganisasikan keseluruhan data program studi yang tersebar dan tidak teratur dengan baik agar lebih mudah dilakukan persiapan sebelum periode penilaian oleh lembaga akreditasi nasional atau BAN-PT.
Saat ini beberapa aplikasi yang memanfaatkan teknologi informasi telah dibuat seperti [3-4]. Namun aplikasi-aplikasi tersebut hanya berdiri sendiri dan perlu dirangkum sehingga bisa menjadi dasar dalam mengumpulkan data untuk kebutuhan akreditasi.

Berdasarkan masalah tersebut maka diperlukan aplikasi manajemen yang mampu mengintegrasikan keseluruhan isi data pendukung sehingga saat proses evaluasi didapatkan informasi mengenai bagian-bagian apa saja yang kurang dan sudah memenuhi standar. Salah satu bentuk aplikasi yang dapat membantu proses persiapan akreditasi adalah dashboard. Dashboard merupakan sebuah alat yang memberikan tampilan antarmuka dalam berbagai bentuk, seperti diagram, laporan, indikator visual, mekanisme alert, yang dipadukan dengan informasi yang dinamis dan relevan [5-6]. Penerapan dashboard pada kalangan institusi akademik dapat memberikan dua manfaat. Pertama adalah memberikan bukti empiris dalam mendukung pengambilan keputusan yang dibentuk berdasarkan data program studi. Kedua adalah alat ini dapat menggambarkan komitmen institusi dalam memberikan pengukuran performa institusional secara multidimensional kepada stakeholder yang membutuhkannya [7]. Visualisasi dashboard diperlukan untuk memperhitungkan posisi performa program studi dengan kondisi lebih mudah diukur, dihitung dan diawasi sehingga pihak intern dapat mengetahui posisi penilaian mereka pada periode tertentu dan mampu memperbaikinya jika kurang dari target yang ditetapkan oleh standar [8].

Berdasarkan uraian tersebut maka peneliti tertarik membangun sistem dashboard untuk mempermudah proses persiapan akreditasi yang disesuaikan dengan 
Borang IIIA. Borang IIIA memiliki peran terbesar dalam proses akreditasi karena memiliki hasil penilaian terbesar dibandingkan dengan instrumen akreditasi program studi yang lain. Sistem dashboard diharapkan mampu menjadi alat bantu yang dapat mengkonversi data pendukung pada borang program studi menjadi sebuah rancangan visualisasi. Hasil rancangan visualisasi dapat dijadikan dasar dalam evaluasi kinerja institusi secara efektif.

\section{PENDEKATAN}

MASALAH

\section{Analisis Sistem}

Analisis sistem merupakan tahapan penguraian dari suatu sistem informasi yang utuh ke dalam bagianbagian komponennya dengan tujuan untuk mengidentifikasikan dan mengevaluasi permasalahan, kesempatan, hambatan yang terjadi dan kebutuhan yang diharapkan sehingga dapat diusulkan perbaikan sistem.

Tahap analisis dilakukan setelah tahap perencanaan sistem dan sebelum tahap desain sistem. Tahap ini merupakan tahap yang kritis karena kesalahan dalam tahap ini menyebabkan kesalahan pada tahap selanjutnya.

\section{Analisis Sistem yang Sedang Berjalan \\ Berdasarkan hasil analisis sistem yang sedang berjalan, diketahui bahwa pengisian borang akreditasi program studi menggunakan data yang terdapat pada program studi serta data dari unit tata usaha di fakultas dan juga perguruan tinggi. Tim penyusun borang akreditasi beserta ketua program studi menyusun isian borang pada masing-masing standar serta dilengkapi dengan lampiran. Hasil pengisian borang akreditasi akan diperiksa dan dievaluasi oleh pihak}

Badan Penjaminan Mutu perguruan tinggi untuk menghasilkan kualitas borang yang lebih baik.

Tabel 1. Analisis User

\begin{tabular}{|c|c|c|}
\hline No & User & Peran \\
\hline 1 & Tim Penyusun & $\begin{array}{l}\text { - Mengumpulkan } \\
\text { dokumen-dokumen } \\
\text { yang diperlukan } \\
\text { sesuai dengan isian } \\
\text { borang } \\
\text { - Mengentri data-data } \\
\text { mahasiswa, dosen, } \\
\text { dan anggaran ke } \\
\text { dalam file excel yang } \\
\text { diberikan borang } \\
\text { - Mengisi buku } 3 \mathrm{~A} \\
\text { akreditasi buku } \\
\text { dan buku 3B }\end{array}$ \\
\hline 2 & Pimpinan PT & 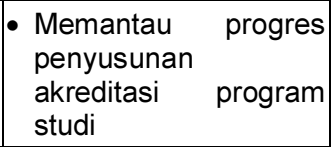 \\
\hline 3 & Asesor Internal & $\begin{array}{ll}\text { - } & \text { Memberikan penilaian } \\
\text { terhadap } & \text { hasil } \\
\text { penyusunan borang } \\
\text { akreditasi } \\
\text { - Memberikan saran- } \\
\text { saran dan masukan } \\
\text { untuk perbaikan } \\
\text { borang akreditasi. }\end{array}$ \\
\hline
\end{tabular}

Hasil analisis user pada sistem yang sedang berjalan dapat digambarkan dalam bentuk activity diagram seperti yang diperlihatkan pada gambar 1 . 


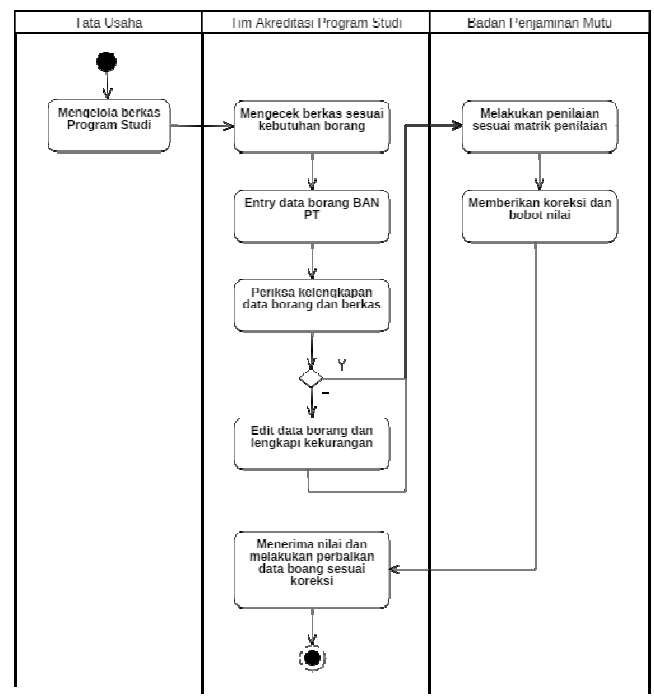

Gambar 1. Activity Diagram Sistem yang sedang berjalan

\section{Analisis Dokumen}

Analisis dokumen merupakan kegiatan pengumpulan informasi mengenai dokumen-dokumen yang digunakan dalam suatu sistem. Tujuan dari analisis dokumen adalah mengetahui dan memahami dokumen-dokumen apa saja yang terlibat dan mengalir dalam suatu sistem yang sedang berjalan.

\section{Analisis Dokumen Input}

Analisis dokumen input meliputi seluruh menu yang disediakan sistem untuk memasukkan data yang dibutuhkan sistem. Adapun data yang dijadikan dokumen input dalam sistem ini merupa data dosen, data mahasiswa dan lulusan, data tenaga kependidikan, data kegiatan dan pelayanan mahasiswa, data peningkatan SDM, data kegiatan penelitian pengabdian dan kerjasama, serta data pembiayaan Untuk lebih jelasnya dapat dilihat pada tabel 2 berikut:

Tabel 2. Analisis Dokumen Input

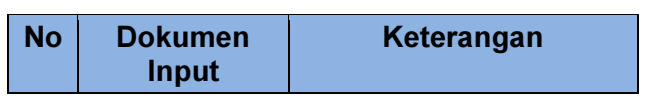

\begin{tabular}{|c|c|c|}
\hline 1 & Data dosen & $\begin{array}{lr}\text { Merupakan } & \text { dokumen } \\
\text { yang berisi data dosen } \\
\text { berupa } & \text { biodata, } \\
\text { pendidikan, } & \text { pangkat, } \\
\text { jabatan, dll. } & \\
\end{array}$ \\
\hline 2 & $\begin{array}{l}\text { Data } \\
\text { mahasiswa } \\
\text { dan lulusan }\end{array}$ & \begin{tabular}{lr} 
Merupakan & \multicolumn{2}{c}{ dokumen } \\
yang berisikan data \\
tentang $\quad$ mahasiswa \\
berupa \\
mahasiswa & jumlah \\
angkatan, & diap \\
tampung, jumlah calon \\
mahasiswa, reguler dan \\
non-reguler, dan jumlah \\
lulusan.
\end{tabular} \\
\hline 3 & $\begin{array}{l}\text { Data tenaga } \\
\text { kependidikan }\end{array}$ & $\begin{array}{l}\text { Merupakan dokumen } \\
\text { yang berisikan data } \\
\text { jumlah tenaga } \\
\text { kependidikan, jenjang } \\
\text { pendidikan, dan unit } \\
\text { kerjanya. }\end{array}$ \\
\hline 4 & $\begin{array}{l}\text { Data kegiatan } \\
\text { dan } \\
\text { pelayanan } \\
\text { mahasiswa } \\
\end{array}$ & \begin{tabular}{|lr} 
Merupakan dokumen \\
yang berisikan data \\
tentang kegiatan \\
pelayanan mahasiswa
\end{tabular} \\
\hline 5 & $\begin{array}{l}\text { Data } \\
\text { peningkatan } \\
\text { SDM }\end{array}$ & $\begin{array}{l}\text { Merupakan dokumen } \\
\text { yang berisikan data } \\
\text { kegiatan peningkatan } \\
\text { kualitas dosen dan } \\
\text { tenaga kependidikan }\end{array}$ \\
\hline 6 & $\begin{array}{l}\text { Data struktur } \\
\text { kurikulum }\end{array}$ & \begin{tabular}{|lr} 
Merupakan dokumen \\
yang berisikan data \\
tentang struktur \\
kurikulum dan data \\
kelengkapan mata kuliah
\end{tabular} \\
\hline 7 & $\begin{array}{l}\text { Data kegiatan } \\
\text { penelitian, } \\
\text { pengabdian, } \\
\text { dan } \\
\text { kerjasama }\end{array}$ & \begin{tabular}{llr}
\multicolumn{2}{l}{ Merupakan dokumen } \\
yang berisikan data \\
tentang kegiatan \\
penelitian r dan \\
pengabdian dosen,
\end{tabular} \\
\hline 6 & \begin{tabular}{l|} 
Data \\
pembiayaan, \\
serta sarana \\
dan prasarana
\end{tabular} & $\begin{array}{l}\text { Merupakan dokumen } \\
\text { yang berisikan data } \\
\text { perolehan dan alokasi } \\
\text { dana, serta sarana dan } \\
\text { prasarana. }\end{array}$ \\
\hline
\end{tabular}

\section{Analisis Dokumen Output}

Analisis dokumen output merupakan seluruh form yang disediakan dalam sistem yang memuat informasi dari hasil data yang diinputkan ke dalam sistem serta informasi yang dikirimkan sistem ke user. Dokumen output dapat dilihat pada tabel 3 berikut :

Tabel 3. Analisis Dokumen Output

\begin{tabular}{|l|l|l|}
\hline No & Dokumen & Keterangan \\
\hline
\end{tabular} 


\begin{tabular}{|c|c|c|}
\hline & Output & \\
\hline 1 & Standar 1 & $\begin{array}{l}\text { Merupakan dokumen yang } \\
\text { berisikan detail informasi } \\
\text { tentang visi, misi, tujuan } \\
\text { dan sasaran, serta strategi } \\
\text { pencapaian program studi }\end{array}$ \\
\hline 2 & Standar 2 & \begin{tabular}{|lr}
\multicolumn{3}{|l}{ Merupakan dokumen yang } \\
berisikan detail & informasi \\
tentang tata & pamong, \\
kepemimpinan, & sistem \\
pengelolaan, & dan \\
penjaminan mutu &
\end{tabular} \\
\hline 3 & Standar 3 & $\begin{array}{l}\text { Merupakan dokumen yang } \\
\text { berisikan detail informasi } \\
\text { tentang mahasiswa dan } \\
\text { lulusan }\end{array}$ \\
\hline 4 & Standar 4 & $\begin{array}{lll}\text { Merupakan dokumen yang } \\
\text { berisikan } & \text { detail informasi } \\
\text { tentang } & \text { sumber daya } \\
\text { manusia } & & \\
\end{array}$ \\
\hline 5 & Standar 5 & $\begin{array}{l}\text { Merupakan dokumen yang } \\
\text { berisikan detail informasi } \\
\text { kurikulum, pembelajaran, } \\
\text { dan suasana akademik }\end{array}$ \\
\hline 6 & Standar 6 & $\begin{array}{l}\text { Merupakan dokumen yang } \\
\text { berisikan detail informasi } \\
\text { tentang pembiayaan, } \\
\text { sarana dan prasarana, } \\
\text { serta sistem informasi }\end{array}$ \\
\hline 7 & Standar 7 & $\begin{array}{l}\text { Merupakan dokumen yang } \\
\text { berisikan detail informasi } \\
\text { tentang penelitian, } \\
\text { pelayanan/pengabdian } \\
\text { kepada masyarakat, dan } \\
\text { kerjasama. }\end{array}$ \\
\hline
\end{tabular}

\section{Analisis Antarmuka}

Analisis antarmuka dilakukan untuk mengetahui bagaimana suatu sistem berinteraksi dengan user/pengguna, serta informasi apa yang akan dipresentasikan sebagai bagian dari suatu antarmuka pengguna. Sistem informasi dokumentasi borang akreditasi program studi menggunakan media atau sarana PC dengan terhubung ke jaringan baik jaringan lokal maupun jaringan internet dalam melakukan input data, kemudian data yang diinputkan tadi akan tersimpan di dalam database sistem informasi, dan akan akan ditampilkan lagi pada halaman sistem informasi tersebut.

\section{Analisis Prosedur}

Analisis prosedur merupakan tahapan yang digunakan untuk menetapkan proses apa saja yang dilakukan oleh sistem. Prosedur yang dapat dilakukan pada sistem yang dibuat seperti terlihat pada tabel 4 .

Tabel 4. Analisis Prosedur

\begin{tabular}{|c|c|c|}
\hline No & $\begin{array}{c}\text { Dokumen } \\
\text { Output }\end{array}$ & Keterangan \\
\hline 1 & $\begin{array}{l}\text { Tim } \\
\text { Penyusun }\end{array}$ & 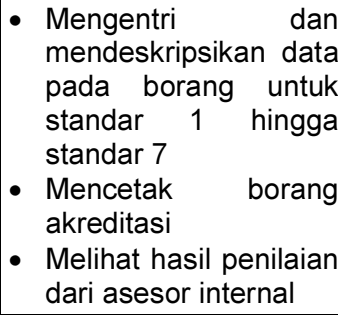 \\
\hline 2 & Pimpinan PT & $\begin{array}{l}\text { - Melihat progres kerja } \\
\text { tim penyusun } \\
\text { - Mencetak borang } \\
\text { akreditasi }\end{array}$ \\
\hline 3 & $\begin{array}{l}\text { Asesor } \\
\text { internal }\end{array}$ & $\begin{array}{l}\text { - Memberikan penilaian } \\
\text { borang akreditasi } \\
\text { - Mencetak borang } \\
\text { akreditasi }\end{array}$ \\
\hline
\end{tabular}

\section{Analisis Tools}

Analisis tools dilakukan untuk menganalisis kebutuhan akan perangkat yang digunakan dalam pengembangan sistem, baik itu analisis kebutuhan perangkat keras dan juga analisis kebutuhan perangkat lunak.

\section{Analisis perangkat keras \\ Spesifikasi}

kebutuhan kebutuhan perangkat keras pada sistem informasi ini minimal meliputi: Processor Intel Pentium 4,, monitor, RAM 2GB, Hardisk minimal $80 \mathrm{~GB}$, VGA Card, USB, Mouse dan Keyboard.

\section{Analisis perangkat lunak \\ Perangkat lunak yang} dibutuhkan yaitu: Sistem Operasi Windows 7 atau versi lainnya, Yii2 sebagai framework yang digunakan, dan MySQL sebagai DBMS. 


\section{Context Diagram}

Context Diagram merupakan gambaran sistem secara logikal, dimana gambaran ini tidak tergantung pada perangkat keras, perangkat lunak ataupun file-file yang digunakan. Keuntungan dari adanya Context Diagram adalah mempermudah pemakai untuk mengerti sistem yang akan dikembangkan. Dalam diagram konteks hanya ada satu proses,tidak boleh ada store dalam diagram konteks Adapun Context Diagram dari sistem baru yang diusulkan adalah sebagai berikut:

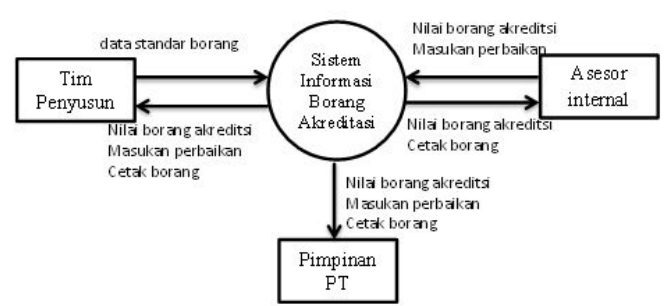

Gambar 2. Context Diagram

\section{Use Case Diagram}

Use case diagram merupakan pemodelan untuk menggambarkan kelakuan (behavior) sistem yang akan dibuat. Dengan menggunakan use case diagram, interaksi antara satu atau lebih aktor dengan sistem yang akan dibuat dapat dideskripsikan. Singkatnya, use case diagram digunakan untuk mengetahui fungsi apa saja yang ada di dalam sebuah sistem dan siapa saja yang berhak menggunakan fungsi-fungsi tersebut.

Gambaran model use case diagram yang akan dibuat dapat dilihat pada gambar 3 .

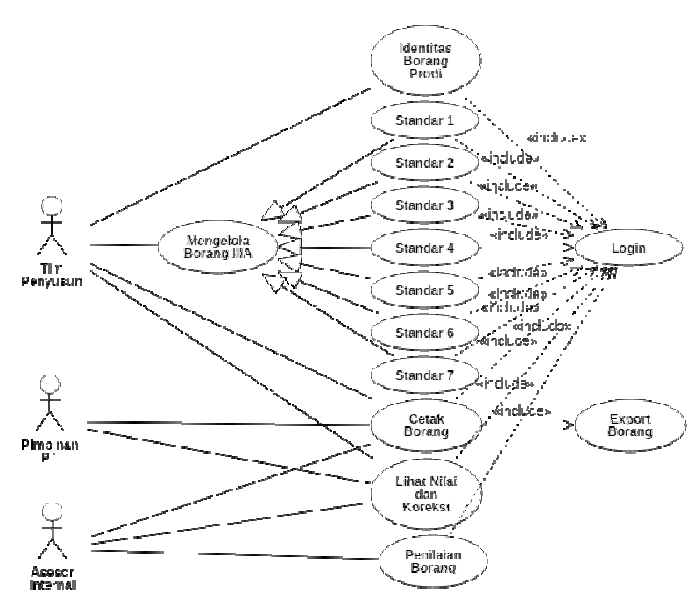

Gambar 3 Use Case Diagram

Use case diagram di atas menggambarkan actor yang terlibat langsung dengan sistem adalah Tim Akreditasi Program Studi sebagai tim penyusun borang akreditasi program studi, asesor internal yang akan menilai dan koreksi untuk peningkatan bobot nilai borang akreditasi, dan pimpinan perguruan tinggi yang dapat memantau progres kerja tim akreditasi program studi.

\section{Activity Diagram}

$$
\text { Activity }
$$

diagram

menggambarkan workflow (aliran kerja) atau aktivitas dari sebuah sistem atau proses bisnis. Yang perlu diperhatikan adalah bahwa activity diagram menggambarkan aktivitas sistem bukan apa yang dilakukan aktor, jadi aktivitas yang dapat dilakukan oleh sistem. Diagram aktivitas mendukung perilaku paralel. Sebuah aktivitas dapat direalisasikan oleh satu use case atau lebih. Aktivitas menggambarkan proses yang berjalan, sementara use case menggambarkan bagaimana aktor menggunakan sistem untuk melakukan aktivitas. 


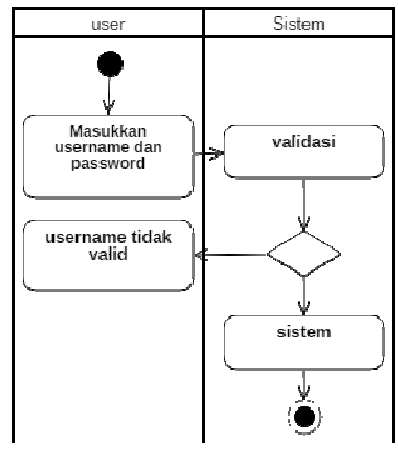

\section{Gambar 4. Activity Diagram Login}

Pada gambar 4 diatas terlihat bahwa setiap user ingin mengakses sistem, maka harus dilakukan proses login terlebih dahulu. Dengan memasukkan username dan password, maka sistem akan melakukan validasi. Jika validasi di terima, maka user dapat masuk ke sistem, dan jika tidak valid maka sistem akan meminta user untuk memasukkan username dan password yang benar.

Activity diagram untuk tim penyusun borang akreditasi dapat dilihat pada gambar 5 . Pada gambar tersebut terlihat bahwa saat tim penyusun sudah masuk ke sistem, maka sistem akan menampilkan halaman menu utama, dan menampilkan menu-menu untuk masing menu borang sesuai dengan standar borang yaitu standar 1, standar 2, standar 3, standar 4, standar 5 , standar 6 , standar 7 , dan identitas borang program studi. Kemudian tim penyusun akan memilih menu yang diinginkan, dimana pada masing-masing menu tersebut ada fitur input, edit, dan delete. Setelah terjadi proses update maka data akan disimpan di database.

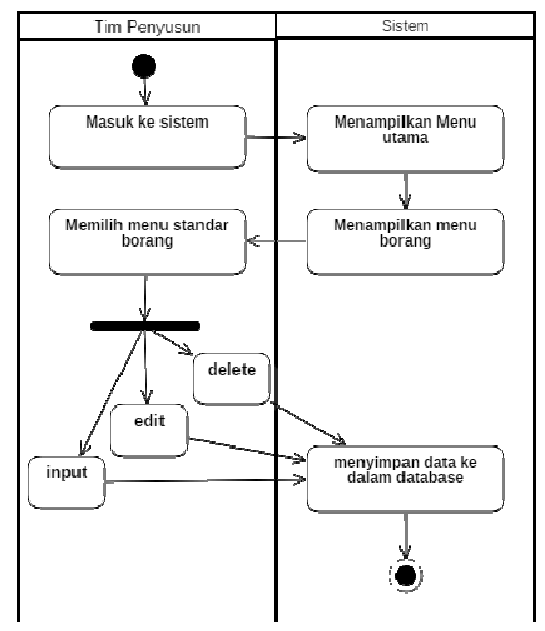

Gambar 5. Activity Diagram Tim Penyusun

Actor lain selain tim penyusun adalah asesor internal. Activity diagram untuk asesor internal ini dapat dilihat pada gambar 6. Dari gambar terlihat bahwa, saat asesor internal masuk ke sistem melalui prosedur login, sistem akan menampilkan menu utama, dan selanjutnya menampilkan menu penilaian borang akreditasi. Selanjutnya asesor internal memilih menu standar borang mana yang akan di nilai. Kemudian asesor internal memberikan penilaian dan masukan pada setiap butir penilaian borang, dan setelah di update maka data akan disimpan di database.

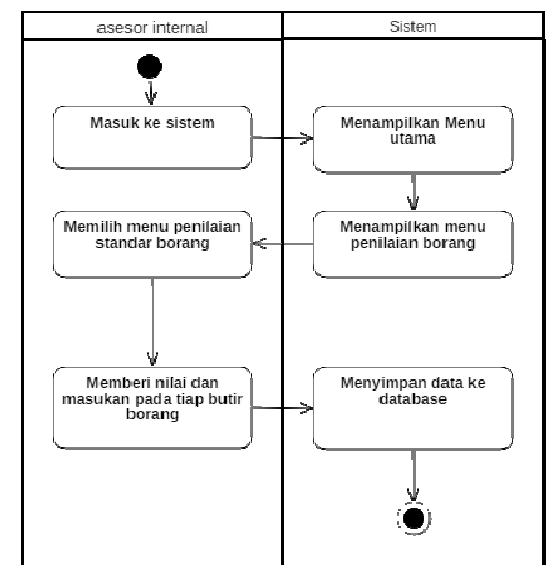

Gambar 6. Activity Diagram Asesor 


\section{Internal}

Pimpinan PT juga merupakan salah satu actor. Pada sistem pimpinan PT dapat melakukan akses dengan fitur melihat progres kerja tim penyusun borang, hasil penilaian asesor internal, dan mencetak borang akreditasi. Activity diagram untuk pimpinan PT digambarkan pada gambar 6 .

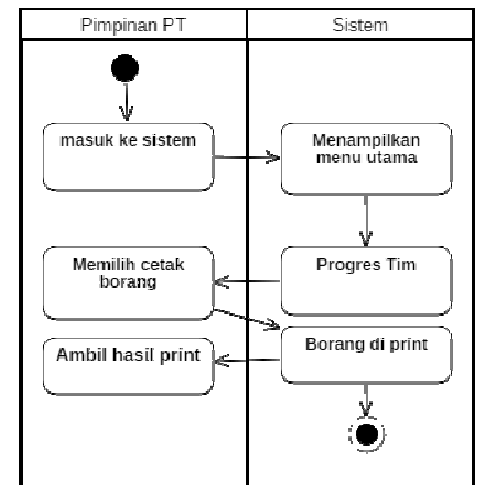

Gambar 6. Activity Diagram Pimpinan PT

\section{Desain Antarmuka}

Berikut adalah rancangan tampilan- tampilan layar aplikasi dengan beberapa pilihan menu yang ada yaitu sebagai berikut :

\section{Menu login}

Sebelum masuk ke menu utama, user terlebih dahulu login seperti pada gambar 7. Bila proses login sukses maka user akan masuk ke menu utama.

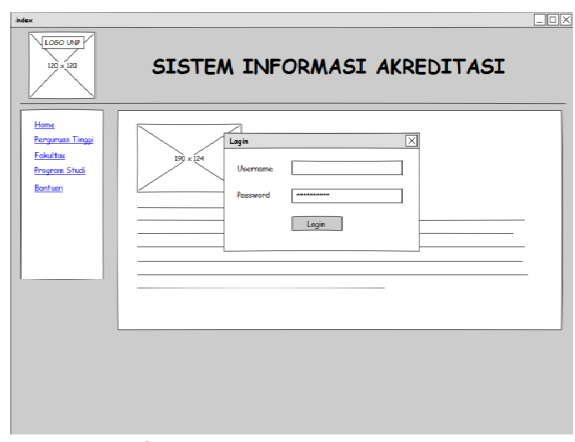

Gambar 7. menu login

\section{Menu program studi}

Pada menu utama user dapat memilih menu program studi seperti terlihat pada gambar 8 .

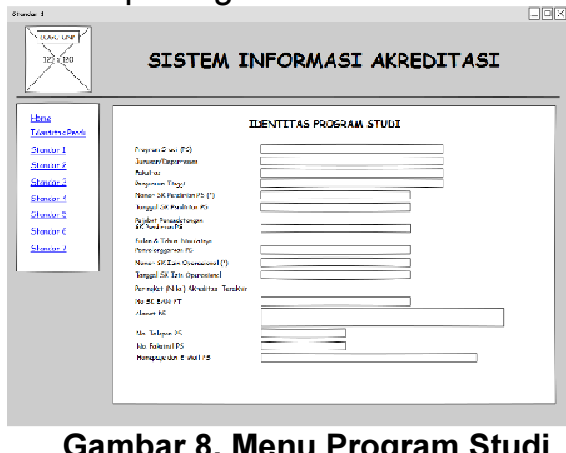

\section{Menu standar 1}

Menu standar 1 merupakan menu tempat mengentri data tentang visi, misi, tujuan dan sasaran, serta strategi pencapaian program studi

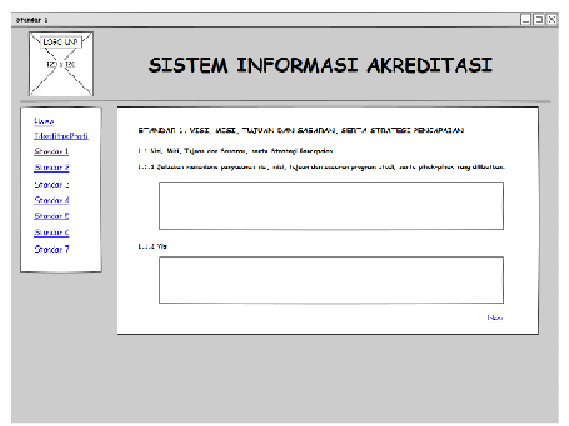

Gambar 9. Menu Standar 1

\section{Menu standar 2}

Menu standar 2 merupakan menu entri data tata pamong, kepemimpinan, sistem pengelolaan, dan penjaminan mutu.

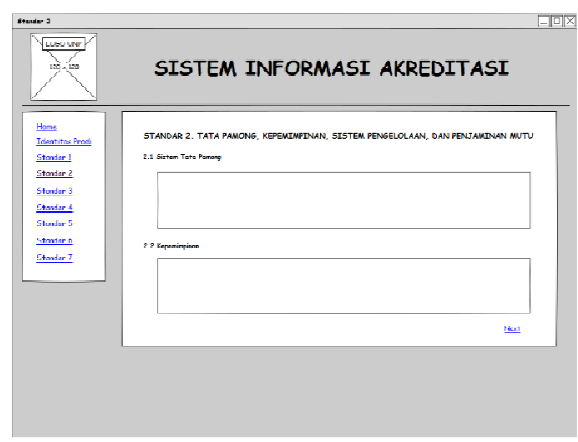

Gambar 10. Menu Standar 2 


\section{Menu standar 3}

Menu standar 3 berisikan data tentang mahasiswa dan lulusan, pada menu ini user cukup mendeskripsikan data yang telah ada.

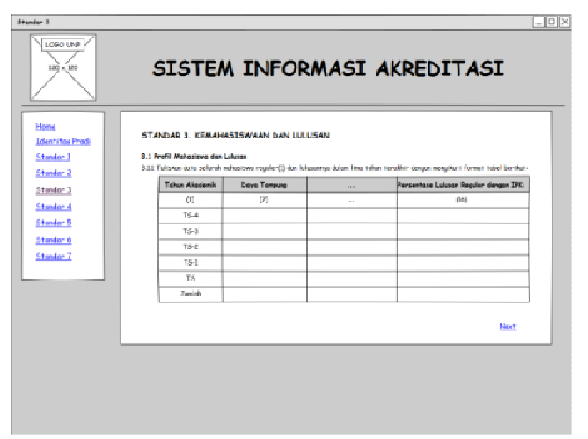

Gambar 11. Menu Standar 3

\section{Menu standar 4}

Menu standar 4 berisikan data tentang sumber daya manusia.

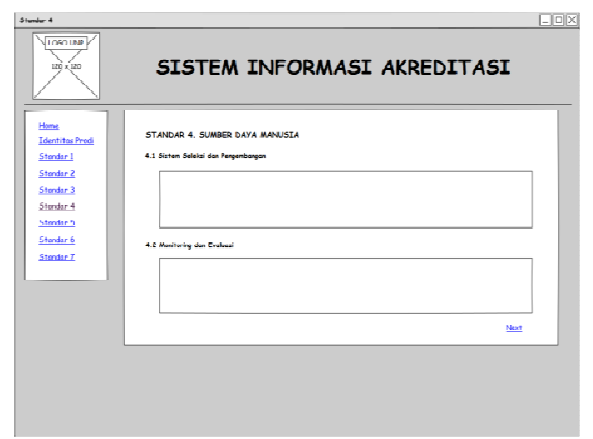

Gambar 12. Menu Standar 4

\section{Menu standar 5}

Menu standar 5 berisikan detail informasi kurikulum pembelajaran dan suasana akademik.

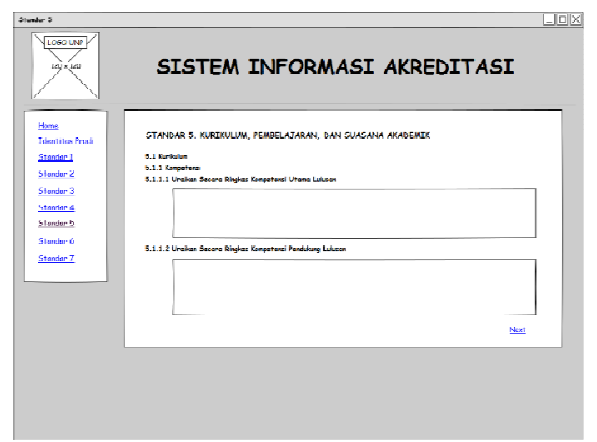

Gambar 13. Menu Standar 5

\section{Menu standar 6 \\ Menu standar 6 merupakan menu entri sarana dan prasarana serta sistem informasi.}

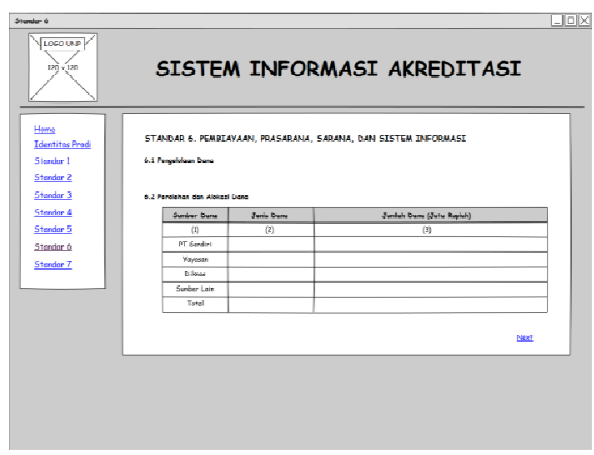

Gambar 14. Menu Standar 6

\section{Menu standar 7 \\ Menu standar 7 berisikan informasi tentang penelitian, pengabdian kepada masyarakat dan kerjasama institusi.}

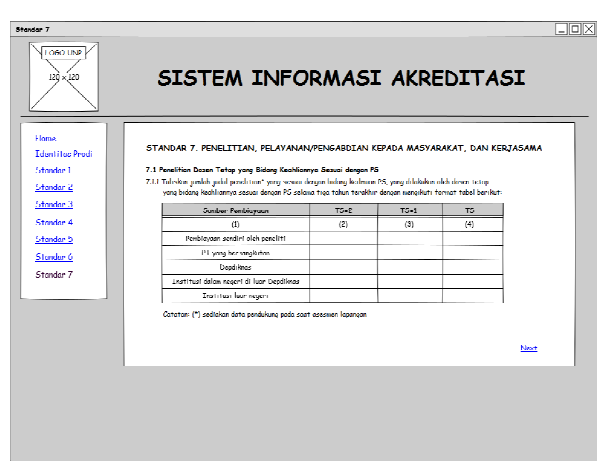

Gambar 15. Menu Standar 7

\section{HASIL DAN PEMBAHASAN}

Berdasarkan rancangan sistem informasi diatas, didapatkan sebuah database sistem informasi dokumentasi borang akreditasi program studi, dimana database tersebut terdiri dari 26 tabel dengan entity relationship diagram seperti pada gambar 16. 


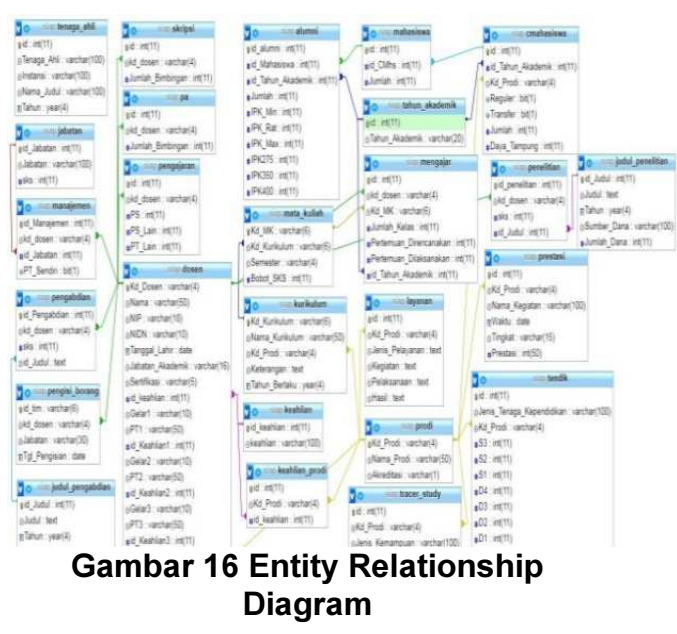

Hasil dari rancangan interface sistem dapat dilihat seperti pada gambar 17. Sistem yang dibuat dapat berjalan pada sistem operasi windows 7 .

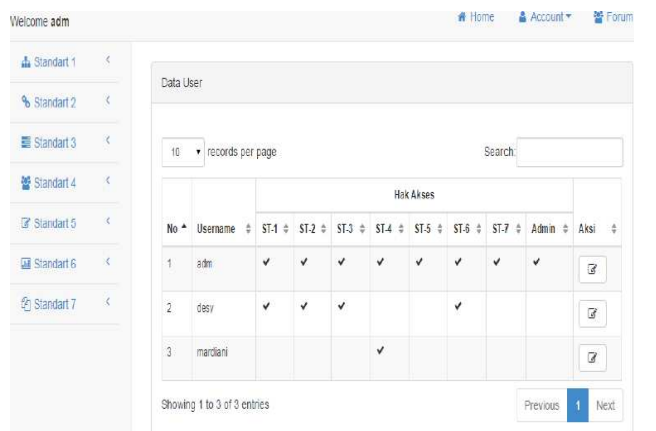

Gambar 17. Antar Muka User

Untuk mengetahui apakah sistem yang dibuat dapat bekerja seperti yang diinginkan, maka dilakukan pengujian, diman pengujian dilakukan secara blackbox testing. Hasil pengujian dapat dilihat pada tabel 5 .

Tabel 5. Hasil Pengujian Secara Blackbox Testing

\begin{tabular}{|c|c|c|c|}
\hline Class & $\begin{array}{l}\text { Hasil yang } \\
\text { diharapkan }\end{array}$ & Pengujian & Hasil Pengujian \\
\hline Login & $\begin{array}{l}\text { Mengisi username } \\
\text { dan password } \\
\text { benar akan } \\
\text { mengaktifkan } \\
\text { halaman menu } \\
\text { pengisian borang }\end{array}$ & $\begin{array}{l}\text { Mengisi } \\
\text { password salah }\end{array}$ & $\begin{array}{l}\text { Muncul pesan } \\
\text { salah, menu } \\
\text { pengisian borang } \\
\text { tidak aktif }\end{array}$ \\
\hline \begin{tabular}{|l} 
Identitas \\
Pengisi \\
Borang
\end{tabular} & $\begin{array}{l}\text { Memasukkan data } \\
\text { tim pengisi borang } \\
\text { akreditasi program } \\
\text { studi, jika disimpan } \\
\text { akan tersimpan } \\
\text { dalam database }\end{array}$ & $\begin{array}{l}\text { Nama pengisi } \\
\text { borang diisi } \\
\text { hanya satu } \\
\text { orang }\end{array}$ & $\begin{array}{l}\text { Muncul pesan } \\
\text { pengisi borang } \\
\text { tidak boleh satu } \\
\text { orang, data tidak } \\
\text { bisa disimpan }\end{array}$ \\
\hline $\begin{array}{l}\text { Standar } \\
3\end{array}$ & $\begin{array}{l}\text { Memasukkan data } \\
\text { tanggapan pihak } \\
\text { pengguna pada } \\
\text { evaluasi lulusan. }\end{array}$ & \begin{tabular}{|l|} 
Data kolom \\
tanggapan \\
pihak pengguna \\
diisi melebih \\
jumlah $100 \%$ \\
\end{tabular} & $\begin{array}{l}\text { Muncul pesan error } \\
\text { bahwa jumlah } \\
\text { persentase melebih } \\
100 \% \text {, data tidak } \\
\text { bisa di simpan. }\end{array}$ \\
\hline $\begin{array}{l}\text { Standar } \\
5\end{array}$ & $\begin{array}{l}\text { Memasukkan data } \\
\text { struktur kurikulum } \\
\text { berdasarkan urutan } \\
\text { mata kuliah. }\end{array}$ & $\begin{array}{l}\text { Pada pengisian } \\
\text { data } \\
\text { kelengkapan } \\
\text { dokumen mata } \\
\text { kuliah diisi } \\
\text { dengan } X \text { bukan } \\
\mathrm{V}\end{array}$ & $\begin{array}{l}\text { Muncul pesan error } \\
\text { bahwa data yang } \\
\text { diisikan salah, data } \\
\text { tidak bisa disimpan }\end{array}$ \\
\hline
\end{tabular}

\section{KESIMPULAN}

Penggunaan sistem informasi dokumentasi borang akreditasi dapat memberikan gambaran tentang posisi nilai akreditasi program studi, sehingga pihak managemen program studi dapat mengambil tindakan untuk mempersiapkan dan memperbaiki kondisi progam studi sehinga bisa mendapat nilai yang maksimal. Sistem informasi ini dibuat mengacu pada panduan penilaian yang dikeluarkan oleh BAN-PT.

\section{DAFTAR RUJUKAN}

[1] BAN-PT. 2008.Buku V Pedoman Penilaian Instrumen Akreditasi Program Studi Sarjana.BAN-PT. Jakarta.

[2] BAN-PT. 2008.Buku II Standar dan Prosedur Akreditasi Institusi Perguruan.BAN-PT. Jakarta.

[3] Fakih A, Raharjana IK, Zaman B. Pemanfaatan Teknologi Fingerprint Authentication untuk Otomatisasi Presensi Perkuliahan. Journal of Information Systems Engineering and Business Intelligence. 2015 Nov 5;1(2):41-8.

[4] Susila CB, Triyono RA. Sistem Informasi Nilai Mahasiswa Berbasis Sms Gateway Pada Sekolah Tinggi Ilmu Tarbiyah 
$\begin{array}{lr}\text { (STIT) } & \text { Muhammadiyah } \\ \text { Pacitan. } & \text { Speed-Sentra } \\ \text { Penelitian Engineering dan } & \text { Edukasi. 2013 Dec 6;7(3). }\end{array}$

[5] Hariyanti E. 2008.

Pengembangan Metodologi

Pembangunan Information

Dashboard Untuk Monitoring

Kinerja Organisasi. e-Indonesia Initiative. Bandung.

[6] Lienita, I. M. 2013. Desain dan

Analisis Prototype Dashboard

Institusi Berdasarkan BAN-PT

(Studi Kasus: INSTITUT

TEKNOLOGI TELKOM).

Telkom University:Skripsi.

[7] Bedi SS, Dayton TW, Stephen B. Using a Dashboard Report Card to Monitor and Report Institutional Performance.

Finding Common Ground: Quality Assurance, Quality Improvement. 2008;4.

[8] Saputro FC, Anggraeni W, Mukhlason A. Pembuatan Dashboard Berbasis Web Sebagai Sarana Evaluasi Diri Berkala untuk Persiapan Penilaian Akreditasi Berdasarkan Standar Badan Akreditasi Nasional Perguruan Tinggi. Jurnal Teknik ITS. 2012 Sep 11;1(1):A397- 402.

[9] BAN-PT. 2008. Buku I Naskah Akademik Akreditasi Program Studi Sarjana. BAN- PT: Jakarta.

[10] Yeni Nuraeni, Perancangan Sistem Informasi Penjaminan Mutu Perguruan Tinggi Bidang Sumber Daya Manusia, Journal of Information Systems, Volume 6, Issues 1, April 2010, hal 32-43

[11] Rasmussen, Bansal, Chen, Business Dashboards: A Visual Catalog for Design and Development, John Wiley \& Sons: New Jersey (2009)

[12] Ian Sommerville. 2004, Software Engineering 7 edition, Pearson Education.

[13] Roger S. Pressman, Ph.D,
2002, Rekayasa Perangkat Lunak, Andi Yogyakarta.

[14] Bambang $\mathrm{H}$, Arie AS. The Development Methodology Of Operational Dashboard As A Tool For Organizational Performance Monitoring (A Case Study: Telkom Polytechnic). Inproceedings intl conf information system business competitiveness 2012 Sep 18.

[15] Eckerson, W. W. Performance dashboards: measuring, monitoring, and managing your business. New Jersey: John Wiley \& Sons: Inc. 2010

[16] BAN-PT. 2008. Buku VI Standar dan Prosedur Akreditasi Institusi Perguruan. BAN- PT. Jakarta. 